University of Nebraska - Lincoln

DigitalCommons@University of Nebraska - Lincoln

USDA National Wildlife Research Center - Staff Publications
U.S. Department of Agriculture: Animal and Plant Health Inspection Service

2012

\title{
Box Traps for Feral Swine Capture: A Comparison of Gate Styles in Texas
}

David B. Long

U.S. Department of Agriculture

Tyler A. Campbell

U.S. Department of Agriculture, tcampbell@eastfoundation.net

Follow this and additional works at: https://digitalcommons.unl.edu/icwdm_usdanwrc

Long, David B. and Campbell, Tyler A., "Box Traps for Feral Swine Capture: A Comparison of Gate Styles in Texas" (2012). USDA National Wildlife Research Center - Staff Publications. 1084.

https://digitalcommons.unl.edu/icwdm_usdanwrc/1084

This Article is brought to you for free and open access by the U.S. Department of Agriculture: Animal and Plant Health Inspection Service at DigitalCommons@University of Nebraska - Lincoln. It has been accepted for inclusion in USDA National Wildlife Research Center - Staff Publications by an authorized administrator of DigitalCommons@University of Nebraska - Lincoln. 


\title{
Box Traps for Feral Swine Capture: A Comparison of Gate Styles in Texas
}

\author{
DAVID B. LONG, United States Department of Agriculture, Animal and Plant Health Inspection Service, Wildlife Services, National Wildlife \\ Research Center, Florida Field Station, 2820 East University Avenue, Gainesville, FL 32641, USA \\ TYLER A. CAMPBELL, ${ }^{1}$ United States Department of Agriculture, Animal and Plant Health Inspection Service, Wildlife Services, National Wildlife \\ Research Center, Florida Field Station, 2820 East University Avenue, Gainesville, FL 32641, USA
}

\begin{abstract}
Many different types of traps have been developed to increase feral swine (Sus scrofa) capture efficiency. Though not previously compared, gate styles may influence capture success. Our objectives were to report feral swine capture data from 31 trapping campaigns conducted in 17 counties from 2005 to 2011 in Texas, USA, compare capture rates by demographic category between side-swing and rooter gates, and evaluate influences of moisture, using the Palmer Drought Severity Index (PDSI), on juvenile capture rates. We trapped feral swine during all months of the year. Our trap configurations were identical with the exception of gate style. Traps had either side-swing or rooter gates. We captured 1,310 feral swine during 2,424 trap-nights. We found no differences in capture rates between gate styles for adults, adult males, or adult females. However, we found juvenile capture rates and total capture rates to differ between gate styles. Box traps with rooter gates captured more juveniles, resulting in more total captures than in box traps with side-swing gates. Partitioned rooter gates are constructed to allow for continual entry after the gate has been tripped; whereas with single-panel side-swine gates, continual entry may be more challenging for juvenile animals that lack the size and strength to push through the spring tension. Rooter gates should be considered over side-swing gates in management programs aimed at overall damage reduction. However, in management or research programs that seek to capture adult feral swine, side-swing gates may be more appropriate because fewer non-target juvenile feral swine are captured. Published 2012. This article is a U.S. Government work and is in the public domain in the USA.
\end{abstract}

KEY WORDS box traps, control, damage, feral swine, rooter gate, side-swing gate, Sus scrofa.

In the United States, feral swine (Sus scrofa) are a widely distributed invasive species that account for extraordinary agricultural and environmental losses. Damage caused by feral swine include food and water contamination (Kaller and Kelso 2006, Jay et al. 2007, Doupé et al. 2010), human and livestock pathogen transmission risks (Hall et al. 2008, Wyckoff et al. 2009), property damage, reduction in crop yields, and competition with native species (Seward et al. 2004). A conservative estimate of US\$ 800 million in annual damage has been reported for feral swine residing in the United States alone (Pimentel et al. 2005).

Natural resource managers in the United States have a variety of control methods available to decrease damage generated by feral swine, including fencing, trapping, snares, aerial and ground shooting, and hunting with dogs (Campbell and Long 2009). Each damage-control method has associated advantages and disadvantages, including costs, labor requirements, safety concerns, legal and social considerations, and appropriate spatial and temporal contexts (Campbell and Long 2009).

Received: 30 November 2011; Accepted: 27 July 2012

${ }^{1}$ E-mail: tyler.a.campbell@aphis.usda.gov
Many different types of traps have been developed and modified to increase capture efficiency (Foreyt and Glazener 1979). However, there are 2 primary types of feral swine traps, portable box traps, and semi-permanent corral traps (Choquenot et al. 1993). Box traps typically have 6 sides (i.e., top, bottom, 2 sides, front, and back), are rectangular in shape, and are available at most hardware and farm-andranch stores in Texas, USA. Corral traps are typically rounded (to keep feral swine from escaping by piling-up in corners), larger in area than box traps, and have no top or bottom. Variation in these 2 trap types may include size, materials used, trigger mechanism, and gate style (West et al. 2009). Different types of traps may be more effective than others depending on personnel time, resources, sounder size, and feral swine behavior (Campbell and Long 2009). For example, a recent study from Fort Benning, Georgia, USA, found feral swine capture rates were 4 times greater for corral traps than for box traps (Williams et al. 2011a). However, in Texas, box traps are often used by landowners and recreationalists because of their availability and portability, and because practitioners are not necessarily attempting to capture feral swine to control damage, but instead are removing a few feral swine for consumption or other utilitarian uses.

Though not previously compared, gate styles may also influence capture success (Williams et al. 2011a). 
Common trap gates include spring-charged saloon gates, spring-charged side-swing gates, gravity-charged guillotine gates, and gravity-charged rooter gates with or without partitions (e.g., for the latter see Belden and Frankenberger 1977). Each of these gates can be triggered or released through feral swine activity at the site of bait placement within the trap, monofilament fishing line or rope tied to the trigger, and a prop placed in such a position that it maintains the gate in an open position (Williams et al. 2011a).

The U.S. Department of Agriculture, Animal and Plant Health Inspection Service, Wildlife Services, National Wildlife Research Center maintained a field station in Kingsville, Texas from 2004 to 2011 aimed at developing new methods for managing feral swine damage and diseases. During this time, field station personnel and their partners captured feral swine using box traps, in partial fulfillment of 8 study protocols. The box traps had either side-swing or partitioned rooter gates. Our objectives were to report capture data from 31 trapping campaigns conducted from 2005 to 2011, compare capture rates by demographic category between side-swing and rooter gates, and evaluate influences of moisture on juvenile capture rates by using the Palmer Drought Severity Index (PDSI). The PDSI measures the duration and intensity of the long-term drought-inducing circulation patterns. Long-term drought is cumulative, so the intensity of drought during the current month is dependent on the current weather patterns plus the cumulative patterns of previous months (NCPC 2011). Based on our experience and without prior scientific evaluation, we did not expect differences between gate styles; however, we expected a positive relationship between PDSI and juvenile capture rates because feral swine are resource-dependent breeders (Taylor et al. 1998).

\section{STUDY AREA}

Our trapping campaigns occurred in 16 counties throughout southern Texas, including Aransas, Brooks, Cameron, Dimmit, Duval, Hidalgo, Jim Hogg, Jim Wells, Kenedy,

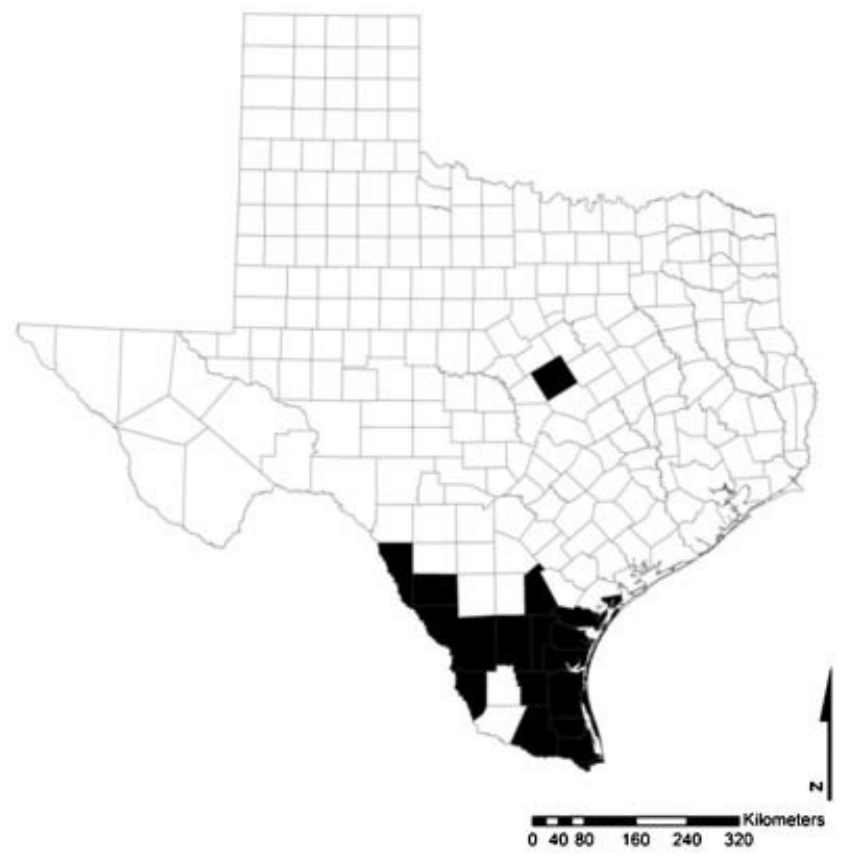

Figure 1. Distribution of the 17 Texas, USA, counties (shaded) in which 31 feral swine (Sus scrofa) trapping campaigns were conducted involving box traps with either side-swing or rooter gates from April 2005 to February 2011.

Kleberg, Live Oak, Nueces, San Patricio, Webb, Willacy, and Zapata counties. We also trapped Fort Hood in Coryell County, which was located in central Texas (Fig. 1). We conducted trapping on 23 private, state, and federal properties, which averaged 13,900 ha; throughout the study, we trapped a total area of 320,000 ha. Precipitation was variable throughout our study (Fig. 2) and monthly moisture for counties during trapping campaigns ranged from extremely moist to extreme drought from 2005 to 2011 (NCPC 2011).

\section{METHODS}

We trapped feral swine during all months of the year (Table 1). Our trap configurations (and price) were identical,

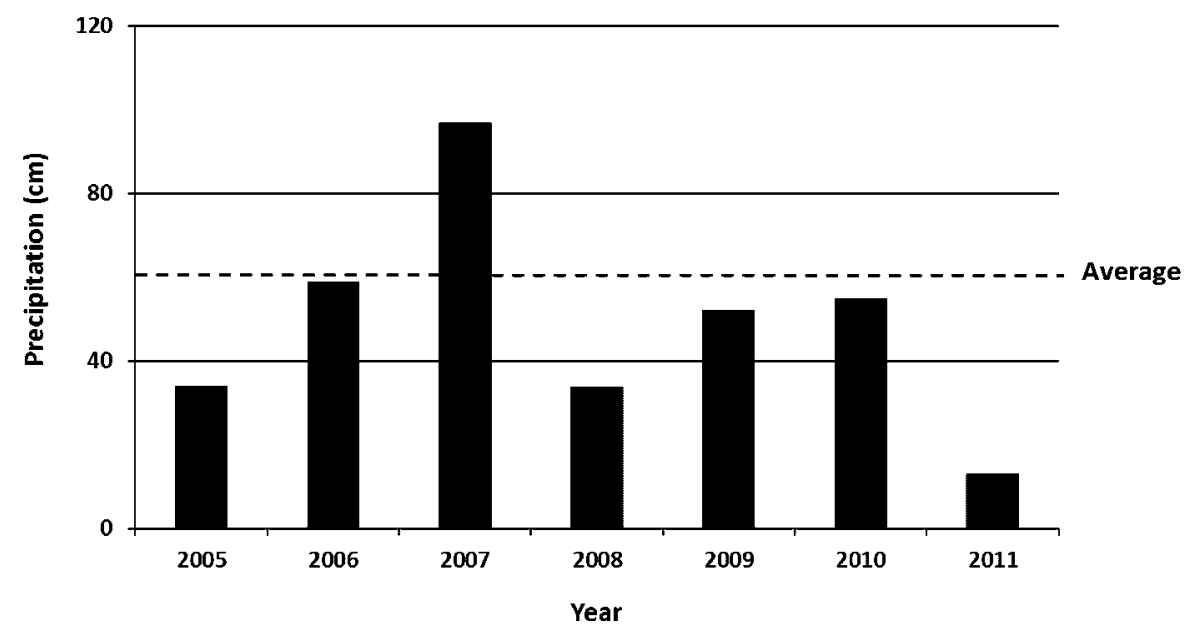

Figure 2. Annual and long-term average precipitation $(\mathrm{cm})$ for Cotulla, Texas, USA, which was a central location of our feral swine (Sus scrofa) trapping campaigns, from April 2005 to February 2011. 
Table 1. County, dates of trapping, bait used, gate style used, total captures, and maximum number of feral swine (Sus scrofa) captured per trap-night during 31 trapping campaigns conducted in Texas, USA, from April 2005 to February 2011.

\begin{tabular}{|c|c|c|c|c|c|}
\hline County & Dates & Bait used & Gate style & Total captures & $\begin{array}{c}\text { Max. no. of } \\
\text { captures/trap-night }\end{array}$ \\
\hline Duval & 20-29 Apr 2005 & Soured corn & Side-swing & 22 & 7 \\
\hline Kleberg & 12 Aug-29 Sep 2005 & Soured corn & Side-swing & 49 & 8 \\
\hline San Patricio & $7-24$ Jun 2006 & Soured grain sorghum & Side-swing & 87 & 12 \\
\hline San Patricio & $21 \mathrm{Nov}-20 \mathrm{Dec} 2006$ & Soured corn & Side swing & 47 & 5 \\
\hline Jim Wells & 18 Dec $2006-3$ Feb 2008 & Dry and soured corn & Side-swing and rooter & 24 & 8 \\
\hline Coryell & 10-29 Jan 2007 & Soured corn & Side-swing and rooter & 17 & 6 \\
\hline Willacy & 23 Jan-9 Feb 2007 & Soured corn & Side-swing & 17 & 4 \\
\hline Willacy & 13-23 Feb 2007 & Soured corn & Side-swing and rooter & 15 & 5 \\
\hline Hidalgo & 13 Feb-1 Mar 2007 & Soured corn & Side-swing and rooter & 16 & 3 \\
\hline Duval & 15 Feb-15 Mar 2007 & Dry corn & Side-swing & 1 & 1 \\
\hline Brooks & $6 \mathrm{Mar}-4 \mathrm{Apr} 2007$ & Soured corn & Side-swing and rooter & 69 & 11 \\
\hline Live Oak & 13 Mar-18 May 2007 & Soured corn & Side-swing and rooter & 79 & 8 \\
\hline Kleberg & 2 Apr-8 May 2007 & Dry corn & Side-swing & 104 & 7 \\
\hline Cameron & 29 Apr-31 May 2007 & Soured corn & Side-swing & 8 & 3 \\
\hline Cameron & 6-22 Jun 2007 & Soured corn & Side-swing & 1 & 1 \\
\hline Cameron & 6-22 Jun 2007 & Soured corn & Side-swing and rooter & 13 & 5 \\
\hline Aransas & 19 Jun-24 Aug 2007 & Soured corn & Side-swing and rooter & 37 & 8 \\
\hline Kleberg & 3-30 Jan 2008 & Soured corn & Side-swing and rooter & 63 & 10 \\
\hline San Patricio & 6-21 May 2008 & Soured corn & Side-swing and rooter & 67 & 10 \\
\hline Kleberg & 3 Feb-25 Sep 2009 & Dry corn & Side-swing and rooter & 8 & 8 \\
\hline Kleberg & 6 Feb-9 Sep 2009 & Dry corn & Side-swing & 8 & 4 \\
\hline Nueces & 18 Feb-9 Sep 2009 & Dry corn & Side-swing & 40 & 14 \\
\hline San Patricio & 10-26 Feb 2010 & Dry corn & Side-swing and rooter & 67 & 6 \\
\hline Brooks & 13-16 Jun 2010 & Soured corn & Side-swing and rooter & 50 & 8 \\
\hline Duval & 21 Jun-26 Aug 2010 & Soured corn & Side-swing and rooter & 102 & 13 \\
\hline Zapata & 20 Jul-19 Aug 2010 & Soured corn & Side-swing and rooter & 90 & 13 \\
\hline Maverick & 19 Jul-17 Aug 2010 & Soured corn & Side-swing and rooter & 53 & 10 \\
\hline Webb & 24 Jul-4 Aug 2010 & Soured corn & Rooter & 19 & 8 \\
\hline Dimmit & 30 Aug-23 Sep 2010 & Soured corn & Side-swing and rooter & 29 & 9 \\
\hline Kenedy & $13-16$ Sep 2010 & Soured corn & Side-swing and rooter & 39 & 9 \\
\hline San Patricio & $3-22 \mathrm{Feb} 2011$ & Dry corn & Side-swing and rooter & 69 & 9 \\
\hline
\end{tabular}

with the exception of gate style. Traps were $2.4 \mathrm{~m}$ in length, $1.2 \mathrm{~m}$ in width, and $0.9 \mathrm{~m}$ in height (Younger Brothers, Seguin, TX). Traps with side-swing gates had an opening of $0.6 \mathrm{~m}$ and consisted of a single panel that pivoted vertically and remained closed by force of spring tension (Fig. 3). Traps with rooter gates had an opening of $1.2 \mathrm{~m}$ and consisted of 4 partitioned panels that pivoted horizontally and remained closed by force of gravity (Fig. 4).

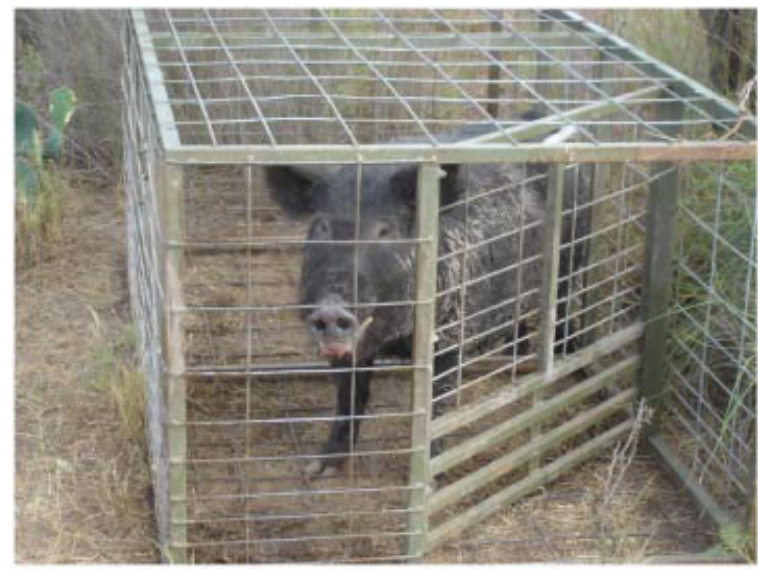

Figure 3. A box trap with side-swing gate used in feral swine (Sus scrofa) trapping campaigns conducted in Texas, USA, from April 2005 to February 2011.
We placed traps in shaded areas adjacent to recent feral swine activity (e.g., rooting), food resources (e.g., deer feeders), and sources of free water. We pre-baited traps with dry whole-kernel corn, soured whole-kernel corn, or soured grain sorghum (Table 1) until feral swine were entering traps and removing bait. We baited, set, and checked traps daily from $0600 \mathrm{hr}$ to $1100 \mathrm{hr}$. Our traps were triggered as previously described above. Upon capture, feral

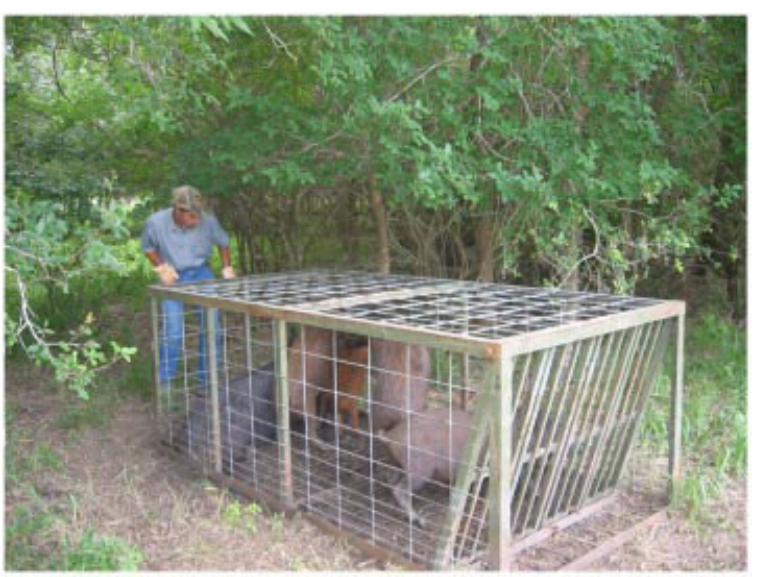

Figure 4. A box trap with rooter gate used in feral swine (Sus scrofa) trapping campaigns conducted in Texas, USA, from April 2005 to February 2011. 
swine were chemically immobilized for marking and collar placement, or killed by a gunshot to the head (AVMA 2007), depending upon the study protocol objectives. We recorded location, gate style, sex, age (adult or juvenile), and total number of animals caught. We determined age based on estimated weight, and considered swine $<22.7 \mathrm{~kg}$ to be juveniles and swine $\geq 22.7 \mathrm{~kg}$ to be adults (Williams et al. 2011a). We released all non-target animals (e.g., collared peccaries [Pecari tajacu]) immediately upon arrival at traps. All capture and handling procedures were approved by the Institutional Animal Care and Use Committee at the National Wildlife Research Center (Permit nos. QA1283, QA-1308, QA-1309, QA-1528, QA-1593, QA1720, QA-1749, QA-1826).

For each demographic category, we standardized capture data among trapping campaigns by dividing the total number of captures by the number of trap-nights. We conducted analyses on the number of captures per 100 trap-nights for adult, adult male, adult female, juvenile, and total captures. We used a 2-tailed, 2-sample rank sum test to compare capture rates between gate styles using PROC NPAR1WAY WILCOXON of the SAS program (Schulman 1992). We determined statistical significance at $\alpha=0.05$. Additionally, we plotted mean juvenile feral swine capture rates (captures/ 100 trap-nights) by PDSI for all juvenile captures to evaluate influences of moisture on juvenile capture rates.

\section{RESULTS}

We captured 1,310 feral swine during 2,424 trap-nights (Table 1). Sex and age ratios were 674 males:636 females and 576 adults: 726 juveniles, respectively. Of the 536 adult feral swine in which sex was recorded (40 adult feral swine were not included due to missing data on sex) we found 282 to be male and 254 to be female. Of our 31 trapping campaigns, 8 trapping campaigns recorded the maximum number of captures per trap-night of $\geq 10$ animals and 18 trapping campaigns recorded the maximum number of captures per trap-night of $\geq 8$ animals.
Table 2. Mean (SE) feral swine (Sus scrofa) capture rate (captures/100 trapnights) for box traps with side-swing and rooter gates during 31 trapping campaigns conducted in 17 Texas counties, USA, from April 2005 to February 2011.

\begin{tabular}{|c|c|c|c|c|c|c|c|c|c|c|}
\hline \multirow[b]{2}{*}{ Gate style } & \multicolumn{2}{|c|}{ Ad } & \multicolumn{2}{|c|}{ Ad M } & \multicolumn{2}{|c|}{$\operatorname{Ad} F$} & \multicolumn{2}{|c|}{ Juv } & \multicolumn{2}{|c|}{ Total } \\
\hline & $\overline{\bar{x}}$ & $\overline{\mathrm{SE}}$ & $\overline{\bar{x}}$ & $\overline{\mathrm{SE}}$ & $\overline{\bar{x}}$ & $\overline{\mathrm{SE}}$ & $\overline{\bar{x}}$ & $\overline{\mathrm{SE}}$ & $\bar{x}$ & SE \\
\hline Side-swing & 23 & 3 & 11 & 2 & 11 & 1 & 31 & 6 & 54 & 8 \\
\hline Rooter & 31 & 5 & 15 & 3 & 16 & 3 & 80 & 23 & 111 & 27 \\
\hline
\end{tabular}

We found no differences in capture rates between gate styles for adults $\left(Z_{48}=1.149, P=0.25\right)$, adult males $\left(Z_{47}=0.663, P=0.507\right)$, or adult females $\left(Z_{47}=1.192\right.$, $P=0.233$; Table 2). However, we found juvenile capture rates $\left(Z_{48}=2.002, P=0.045\right)$ and total capture rates $\left(Z_{48}=2.04 ; P=0.041\right)$ to differ between gate styles. Box traps with rooter gates captured more juveniles (which resulted in more total captures) than did box traps with sideswing gates (Table 2). Furthermore, we found no relationship between mean juvenile feral swine capture rates and PDSI (Fig. 5).

\section{DISCUSSION}

Our discovery of greater juvenile and total trapping effectiveness for rooter gates was counter to our hypothesis. However, partitioned rooter gates are constructed to allow for continual entry after the gate has been tripped; whereas, with single-panel side-swine gates, continual entry may be more challenging for juvenile animals that lack the size and strength to push through the spring tension. We believe this likely explains our observed differences between gate styles for juvenile capture rates, though we did not document this with direct or photographic observations. Similarly, researchers in France that studied wild boar observed capture rates of adult females with gravity-charged guillotine gates, which did not allow for continual entry, to be less than remotely triggered gates (Fournier et al. 1995). An alternative explanation for greater juvenile trapping effectiveness

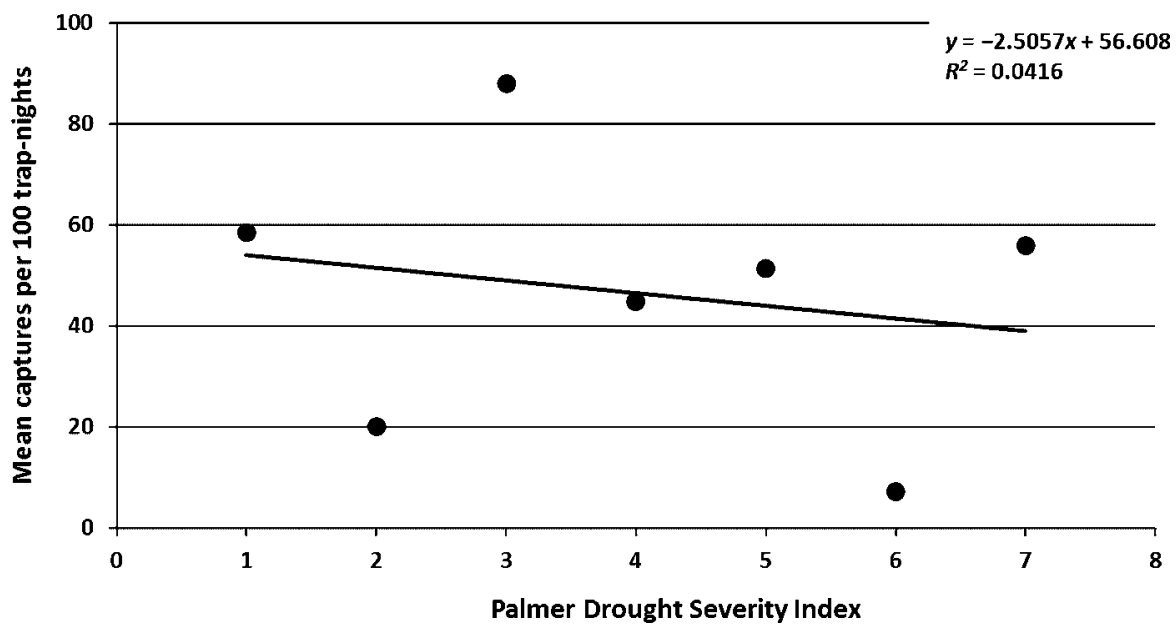

Figure 5. Mean juvenile feral swine (Sus scrofa) capture rates (captures/100 trap-nights) plotted by Palmer Drought Severity Index (PDSI) for box-trap captures during 31 trapping campaigns conducted in 17 Texas counties, USA, from April 2005 to February 2011. PDSI $1=$ extremely moist, PDSI $2=$ very moist, PDSI 3 = moderately moist, PDSI $4=$ average moisture, PDSI $5=$ moderate drought, PDSI $6=$ severe drought, PDSI $7=$ extreme drought (NCPC 2011). 
with rooter gates is that these gates were approximately twice as wide as side-swing gates and may have allowed more juveniles to enter the trap.

Also counter to our hypothesis, we found no relationship between PDSI, which incorporates monthly temperatures and precipitation, and juvenile capture rates. Our hypothesis was based on the observation that the more favorable moisture conditions are, the more reproductively active feral swine would be (Taylor et al. 1998). It is plausible that feral swine breeding activities in Texas are more determined by the state's bimodal precipitation and seasonal temperature patterns (Taylor et al. 1998) and less influenced by monthly variation in moisture. Alternatively, many landowners in Texas provide feed, including corn and protein pellets, to supplement white-tailed deer (Odocoileus virginianus) populations. However, much of this feed is consumed by nontarget wildlife, such as feral swine (Lambert and Demarais 2001). These added nutritional resources may facilitate feral swine reproduction during unfavorable moisture conditions, when they otherwise would be unlikely to reproduce.

Researchers at Fort Benning, Georgia, found adult male feral swine averse to entering box traps and subsequent capture (Williams et al. 2011a). However, we found that $53 \%$ of the adult feral swine captured were male. Although we do not know the proportion of the adult population that was male and female before and after our trapping campaigns (and, therefore, we were unable to determine whether our captures were biased by sex; Choquenot et al. 1993), we can conclude that adult male feral swine regularly entered box traps and were captured frequently. We attribute these differences in behavior to the fact that feral swine populations upon which we conducted our trapping campaigns were relatively naïve to trapping. In fact, for many of the feral swine we captured, our traps were the first that they would have encountered; whereas, feral swine at Fort Benning were highly persecuted (Sparklin et al. 2009). Further illustrating the naivety within our feral swine populations, we found $26 \%$ of our trapping campaigns to record capture events of $\geq 10$ animals and $58 \%$ of our trapping campaigns to record capture events of $\geq 8$ animals. Box traps may be more effective within feral swine populations that have not experienced intensive prior management.

Trapping success is highly variable and dependent on many factors, such as feral swine density, alternate food sources, and duration of pre-baiting (Williams et al. 2011b). Our capture data revealed a pooled mean (total captures for both gate styles) of 54 swine per 100 trap-nights, which ranged by trapping campaign from 10 to 190 swine per 100 trap-nights. Previous research in southern and eastern Texas found boxtrap captures of 16 and 13 swine per 100 trap-nights, respectively (Wyckoff et al. 2006). Other studies using box and corral traps outside of Texas have found similar feral swine capture rates. For example, at Fort Benning, Georgia, researchers captured 23 swine per 100 trap-nights using corral traps and 14 swine per 100 trap-nights using box traps (Williams et al. 2011a); whereas, in Australia researchers captured 40 swine per 100 trap-nights (Saunders et al. 1993) and 250 swine per 100 trap-nights (Caley 1994) in corral traps. Variation in trap success between these studies was likely due to trapping methodology, such as pre-baiting, trap density, feral swine density, trap placement, and prior management. Consequently, we do not believe it prudent to make universal recommendations on styles of traps, because capture success is highly unpredictable. We do recommend developing and implementing a comprehensive feral swine damage-management plan that integrates all legal and socially acceptable techniques for controlling feral swine damage (Campbell and Long 2009).

\section{MANAGEMENT IMPLICATIONS}

Our observed differences in total capture rates between gate styles suggest that box traps with rooter gates are more effective than box traps with side-swing gates. Consequently, rooter gates should be considered over side-swing gates in management programs aimed at overall damage reduction. However, in management or research programs that seek to capture adult feral swine (such as targeted pathogen surveillance; Campbell et al. 2011) or for placement of GPS collars (Campbell et al. 2010), side-swing gates may be more appropriate because fewer non-target juvenile feral swine are captured.

\section{ACKNOWLEDGMENTS}

The study was funded by U.S. Department of Agriculture (USDA), Animal and Plant Health Inspection Service, Wildlife Services, National Wildlife Research Center. We thank the landowners and managers that granted property access. We thank the many technicians, volunteers, and graduate students who provided assistance with trapping and data recording. Logistical support was provided by the Caesar Kleberg Wildlife Research Institute at Texas A\&M University-Kingsville and Texas Wildlife Services. The USDA does not endorse products mentioned in this study.

\section{LITERATURE CITED}

American Veterinary Medical Association [AVMA]. 2007. AVMA guidelines on euthanasia. American Veterinary Medical Association, Schaumburg, Illinois, USA.

Belden, R. C., and W. B. Frankenberger. 1977. A portable root-door hog trap. Proceedings of the Southeastern Association of Fish and Wildlife Agencies 31:123-125.

Caley, P. 1994. Factors affecting the success rate of traps for catching feral pigs in tropical habitat. Wildlife Research 21:287-292.

Campbell, T. A., and D. B. Long. 2009. Feral swine damage and damage management in forested ecosystems. Forest Ecology and Management 257:2319-2326.

Campbell, T. A., D. B. Long, L. R. Bazan, B. V. Thomsen, S. RobbeAusterman, R. B. Davey, L. A. Soliz, S. R. Swafford, and K. C. VerCauteren. 2011. Absence of Mycobacterium bovis in feral swine (Sus scrofa) from the southern Texas border region. Journal of Wildlife Diseases 47:974-978.

Campbell, T. A., D. B. Long, and B. R. Leland. 2010. Feral swine behavior relative to aerial gunning in southern Texas. Journal of Wildlife Management 74:337-341.

Choquenot, D., R. J. Kilgour, and B. S. Lukins. 1993. An evaluation of feral pig trapping. Wildlife Research 20:15-22.

Doupé, R. G., J. Mitchell, M. J. Knott, A. M. Davis, and A. J. Lymbery. 2010. Efficacy of exclusion fencing to protect ephemeral floodplain lagoon 
habitats from feral pigs (Sus scrofa). Wetlands Ecology and Management 18:69-78.

Foreyt, W. J., and W. C. Glazener. 1979. A modified box trap for capturing feral hogs and white-tailed deer. Southwestern Naturalist 24:377-380.

Fournier, P., D. Maillard, and C. Fournier-Chambrillon. 1995. Use of spotlights for capturing wild boar (Sus scrofa). IBEX Journal of Mountain Ecology 3:131-133.

Hall, J. S., R. B. Minnis, T. A. Campbell, S. Barras, R. W. DeYoung, K. Pabilonia, M. L. Avery, H. Sullivan, L. Clark, and R. G. McLean. 2008. Influenza exposure in feral swine from the United States. Journal of Wildlife Diseases 44:362-368.

Jay, M. T., M. Cooley, D. Carychao, G. W. Wiscomb, R. A. Sweitzer, L. Crawford-Miksza, J. A. Farrar, D. K. Lau, J. O'Connell, A. Millington, R. V. Asmundson, E. R. Atwill, and R. E. Mandrell. 2007. Escherichia coli O157: H7 in feral swine near spinach fields and cattle, central California coast. Emergent Infectious Diseases 13:1908-1911.

Kaller, M. D., and W. E. Kelso. 2006. Swine activity alters invertebrate and microbial communities in a Coastal Plain watershed. American Midland Naturalist 156:163-177.

Lambert, B. C., and S. Demarais. 2001. Use of supplemental feed for ungulates by non-target species. Southwestern Naturalist 46:118-121.

National Climate Prediction Center [NCPC]. 2011. Palmer Drought Severity Index Maps. NOAA/National Weather Service, College Park, Maryland, <http://www.cpc.ncep.noaa.gov/products/monitoring_and_ data/drought.shtml >. Accessed 25 Oct 2011.

Pimentel, D., R. Zuniga, and D. Morrison. 2005. Update on the environmental and economic costs associated with alien-invasive species in the United States. Ecological Economics 52:273-288.

Saunders, G., K. Barry, and H. Nicol. 1993. Factors affecting bait uptake and trapping success for feral pigs (Sus scrofa) in Kosciusko National Park. Wildlife Research 20:653-665.
Schulman, R. S. 1992. Statistics in plain English with computer application. Chapman and Hall, New York, New York, USA.

Seward, N. W., K. C. VerCauteren, G. W. Witmer, and R. M. Engeman. 2004. Feral swine impacts on agricultural and the environment. Sheep and Goat Research Journal 19:24-40.

Sparklin, B. D., M. S. Mitchell, L. B. Hanson, D. B. Jolley, and S. S. Ditchkoff. 2009. Territoriality of feral pigs in a highly persecuted population on Fort Benning, Georgia. Journal of Wildlife Management 73:497-502.

Taylor, R. B., E. C. Hellgren, T. M. Gabor, and L. M. Ilse. 1998. Reproduction of feral pigs in southern Texas. Journal of Mammalogy 79:1325-1331.

West, B. C., A. L. Cooper, and J. B. Armstrong. 2009. Managing wild pigs: a technical guide. Human-Wildlife Interactions Monograph 1: $1-55$.

Williams, B. L., R. W. Holtfreter, S. S. Ditchkoff, and J. B. Grand. 2011a. Trap style influences wild pig behavior and trapping success. Journal of Wildlife Management 75:432-436.

Williams, B. L., R. W. Holtfreter, S. S. Ditchkoff, and J. B. Grand. $2011 b$. Efficacy of time-lapse intervals and simple baits for camera surveys of wild pigs. Journal of Wildlife Management 75:655-659.

Wyckoff, A. C., S. E. Henke, T. A. Campbell, D. G. Hewitt, and K. C. VerCauteren. 2009. Feral swine contact with domestic swine: a serologic survey and assessment of potential for disease transmission. Journal of Wildlife Diseases 45:422-429.

Wyckoff, A. C., S. E. Henke, T. A. Campbell, and K. C. VerCauteren. 2006. Is trapping success of feral hogs dependent upon weather conditions? Proceedings of the Vertebrate Pest Conference 22:370-372.

Associate Editor: Rollins. 